\title{
Sea ice microbial communities. VII. Changes in under-ice spectral irradiance during the development of Antarctic sea ice microalgal communities
}

\author{
Anna C. Palmisano ${ }^{1, *}$, Janice Beeler SooHoo ${ }^{1}$, Richard L. Moe ${ }^{2}$ \\ \& Cornelius W. Sullivan ${ }^{3}$ \\ ${ }^{1}$ Allan Hancock Foundation, University of Southern California, Los Angeles, California 90089-0371, USA \\ ${ }^{2}$ Department of Botany, University of California, Berkeley, California 94704, USA \\ ${ }^{3}$ Department of Biological Sciences, University of Southern California, Los Angeles, California 90089-0371, USA
}

\begin{abstract}
Changes in spectral irradiance beneath annual sea ice were measured during the development of sea ice microalgal communities in McMurdo Sound, Antarctica. Five different light regimes were initially established by varying surface snow cover on $10 \mathrm{~m} \times 10 \mathrm{~m}$ sea ice quadrats. The presence of ice algae in quadrats with $\leqslant 5 \mathrm{~cm}$ snow cover was indicated by a spectral shift with increased attenuation between 400 and $550 \mathrm{~nm}$ and at $671 \mathrm{~nm}$, wavelengths absorbed by diatom pigments. Snow cover had a profound effect on both the rate of community development and community loss by ice ablation. A simple model of factors determining changes in ice algal biomass is described.
\end{abstract}

\section{INTRODUCTION}

It has been well established that the presence of phytoplankton in oceanic environments alters the spectral composition of submarine light (Kirk 1975, Morel 1978, Baker \& Smith 1982, Kiefer \& SooHoo 1982, Kishino et al. 1984, and others). In the deep layers of highly productive waters, green to yellowgreen wavelengths predominate because they are poorly absorbed by most phytoplankton pigments (Jerlov 1976). Similar to phytoplankton, microalgae in sea ice possess pigments that absorb wavelengths of light critical for photosynthesis. Beneath Arctic sea ice, Maykut \& Grenfell (1975) found a strong absorption band in the 400 to $550 \mathrm{~nm}$ region which they attributed to microalgae in sea ice without actually confirming their presence. During the austral spring in McMurdo Sound, Antarctica, microalgae (primarily diatoms) grow in the bottom $20 \mathrm{~cm}$ of hard congelation ice

- Present address: NASA-Ames Research Center, Mail Stop 239-4, Moffett Field, California 94035, USA
(Palmisano \& Sullivan 1983) and in the unconsolidated ice platelet layer below (Bunt 1963, Bunt \& Lee 1970, Sullivan et al. 1983). In a preliminary report, Sullivan et al. (1984) showed that the presence of diatoms in sea ice at McMurdo Sound affected both the photosynthetically available radiation (PAR) and the spectral composition of under-ice irradiance.

The principal light-absorbing pigments of diatoms are chlorophyll $a$, chlorophyll $c$, fucoxanthin, diadinoxanthin, diatoxanthin, and $\beta$-carotene (Mann \& Myers 1968). Diatoms absorb spectral irradiance primarily between 400 and $550 \mathrm{~nm}$ (both chlorophylls and carotenoids) and at about $675 \mathrm{~nm}$ (chlorophyll a). Thus, the presence of diatoms in sea ice results in the differential attenuation of spectral downwelling irradiance. In turn, under-ice attenuation of light in the wavelengths absorbed by diatom pigments may be used to infer the presence of sea ice microalgal communities.

The purpose of this study was to demonstrate that it is possible to follow the development of sea ice microalgal communities using a spectroradiometer. 
Changes in spectral downwelling irradiance beneath sea ice were followed during the development of sea ice microalgal communities under different light regimes, established by varying surface snow cover. The relation between changes in under-ice spectra and the presence of ice microalgae is corroborated by the companion report (Grossi et al. 1987) where detailed ice algal biomass estimates (chlorophyll a) are presented.

\section{METHODS}

Study site. Our study site was annual sea ice about $100 \mathrm{~m}$ north of Cape Armitage in McMurdo Sound $\left(77^{\circ} 51^{\prime} S_{i} 166^{\circ} 40^{\prime} \mathrm{E}\right)$. McMurdo Sound is the southernmost extension of the Ross Sea.

Experimental design. Two parallel experiments were conducted in which surface snow was used to manipulate the under-ice light field; natural snow cover was $25 \mathrm{~cm}$. In Experiment I, snow was added to or removed from 5 quadrats $(10 \mathrm{~m} \times 10 \mathrm{~m})$ to achieve surface snow cover of $0,5,10,25$, or $100 \mathrm{~cm}$ on 9 October 1982. (These quadrats are designated Q-0, Q-5, Q-10, Q-25, and Q-100 by Grossi et al. 1987.) Snow levels were maintained on these quadrats throughout the study which was terminated on 27 December 1982. In Experiment II, 5 quadrats were set up as in the first set on 9 October, except that snow was cleared from all 5 quadrats on 3 December. Because of time constraints on dive logistics, spectral data were not collected on the same dates in Experiments I and II.

Under-ice spectra were measured intermittently (every 1.5 to $3 \mathrm{wk}$ ) between 10 November and 27 December by SCUBA divers using a MER 1000 spectroradiometer (Biospherical Instruments, San Diego) with a cosine collector. This diver-operated instrument has been described in detail by Kishino et al. (1984). Briefly, irradiance at wavelengths of 410 , $441,488,520,540,570,589,625,656,671$, and $694 \mathrm{~nm}$ as well as total photosynthetically available radiation (PAR) were measured and recorded on an internal printer.

Despite relatively constant surface irradiance, under-ice spectra were measured between 1100 to $1300 \mathrm{~h}$ to avoid diurnal effects beneath sea ice resulting from changes in sun angle (Sullivan et al. 1982). Irradiance measurements were made directly below the platelet ice layer at 3 to 5 sites per quadrat. Spectra at replicate sites were averaged; standard deviations at individual wavelengths were generally $< \pm 10 \%$ of the means. Congelation ice thickness was determined by dropping a marked line through a hole that had been drilled through the hard ice. Total ice depth (congelation ice + platelet ice) was determined by a depth transducer on the spectroradiometer. Platelet ice thickness was approximated as the difference between total ice thickness and congelation ice thickness.

Calculations. The spectral diffuse attenuation coefficient $K_{T}(\lambda)$ was calculated according to Equation (2) of Baker \& Smith (1982):

$$
\mathrm{K}_{\mathrm{T}}(\lambda)=\left[-1 /\left(\mathrm{z}_{2}-\mathrm{z}_{1}\right)\right] \ln \left[\mathrm{E}\left(\mathrm{z}_{2}, \lambda\right) / \mathrm{E}\left(\mathrm{z}_{1}, \lambda\right)\right]
$$

where $E\left(z_{1}, \lambda\right)$ and $E\left(z_{2}, \lambda\right)=$ spectral irradiance measurements at 2 depths, $z_{1}$ and $z_{2}$. As we apply this equation to sea ice, $E\left(z_{1}\right)$ represents net surface downwelling irradiance while $E\left(z_{2}\right)$ represents irradiance beneath annual sea ice. An albedo of $91.8 \%$, measured by suspending the spectroradiometer $\sim 1.5 \mathrm{~m}$ above snow covered ice, was subtracted from the total surface downwelling irradiance to estimate net surface downwelling irradiance. Albedo does not appear to exhibit strong spectral variation in the visible (Grenfell $\&$ Maykut 1977). The total pathlength, $z_{2}-z_{1}$, is the sum of the thicknesses of congelation ice, platelet ice, and snow cover.

\section{RESULTS}

Congelation, platelet, and total ice thicknesses are shown in Table 1. In Experiment I, ice thickness generally reached a peak by late November. In Experiment II, removal of snow on 3 December was followed by a decrease in total ice thickness in all quadrats. This decrease was primarily the result of the loss of the ice platelet layer. The greatest ice thickness, $3.22 \mathrm{~m}$, was reached under $100 \mathrm{~cm}$ snow cover. It should be noted that the platelet ice thickness is only an approximation based on the assumption that divers held the spectroradiometer just below the platelet ice during sampling. The difficulty of manipulating the bulky spectroradiometer underwater makes it likely that platelet ice thickness may have been overestimated. Overall trends in estimated platelet ice thickness, however, correspond to visual observations of ice thickness by divers.

Total PAR (Table 2) and percent downwelling irradiance $\left(\% \mathrm{I}_{\text {; }}\right.$ Table 3$)$ varied as a function of snow cover and time. Total PAR beneath sea ice with $100 \mathrm{~cm}$ snow cover was below the limit of detection of our

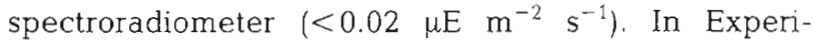
ment $I_{1}$ irradiance beneath sea ice with $0 \mathrm{~cm}$ snow cover dropped sharply between 9 and 19 November as a golden-brown microalgal community developed. Irradiance increased by 30 November as the platelet ice ablated and the associated microalgae were lost. Removal of snow cover in Experiment II resulted in a sharp increase in PAR in the 5 to $100 \mathrm{~cm}$ snow quadrats. Irradiance subsequently dropped under $5 \mathrm{~cm}$ snow cover as a microalgal community developed; 
PAR then increased by 27 December as the algae were lost during ice ablation.

The spectral composition of downwelling irradiance is shown in Fig. 1 (Experiment I) and Fig. 2 (Experiment II). Under-ice spectra beneath $10 \mathrm{~cm}$ of snow, where a microalgal community was not visually apparent to divers, showed a broad peak between 400 and $550 \mathrm{~nm}$. Snow and ice attenuated longer and, to a lesser degree, shorter wavelengths. The presence of ice algae was indicated by changes in under-ice

Table 1. Congelation ice and platelet ice thicknesses $(\mathrm{m})$ in quadrats with different snow cover

\begin{tabular}{|c|c|c|c|c|c|c|c|c|}
\hline \multirow[b]{2}{*}{ Snow $(\mathrm{cm})$} & \multirow[b]{2}{*}{ Ice } & \multicolumn{3}{|c|}{ Experiment I } & \multicolumn{4}{|c|}{ Experiment II (snow removed 3 Dec) } \\
\hline & & 13 Nov & 30 Nov & $24 \mathrm{Dec}$ & $2 \mathrm{Dec}$ & $7 \mathrm{Dec}$ & $17 \mathrm{Dec}$ & $27 \mathrm{Dec}$ \\
\hline \multirow[t]{3}{*}{0} & Congelation & 2.21 & 2.19 & 2.17 & 2.18 & 2.18 & 2.18 & 2.14 \\
\hline & Platelet & 0.43 & 0.45 & 0.45 & 0.54 & 0.76 & 0.30 & 0.17 \\
\hline & Total & 2.64 & 2.64 & 2.62 & 2.62 & 2.94 & 2.48 & 2.31 \\
\hline \multirow[t]{3}{*}{5} & Congelation & 2.18 & 2.29 & 2.25 & 2.27 & 2.27 & 2.27 & 2.23 \\
\hline & Platelet & 0.47 & 0.69 & 0.84 & 0.85 & 1.35 & 0.71 & 0.40 \\
\hline & Total & 2.65 & 2.98 & 3.09 & 3.12 & 3.62 & 2.98 & 2.63 \\
\hline \multirow[t]{3}{*}{10} & Congelation & 2.18 & 2.29 & 2.25 & 2.26 & 2.26 & 2.26 & 2.22 \\
\hline & Platelet & 0.36 & 0.83 & 0.68 & 0.87 & 0.99 & 0.83 & 0.30 \\
\hline & Total & 2.54 & 3.12 & 2.93 & 3.13 & 3.25 & 3.09 & 2.52 \\
\hline \multirow[t]{3}{*}{25} & Congelation & 2.18 & 2.23 & 2.23 & 2.22 & 2.22 & 2.22 & 2.18 \\
\hline & Platelet & 0.32 & 0.79 & 0.61 & 1.02 & 1.14 & 0.79 & 0.24 \\
\hline & Total & 2.50 & 3.02 & 2.84 & 3.24 & 3.36 & 3.01 & 2.42 \\
\hline \multirow[t]{3}{*}{100} & Congelation & 2.23 & ND & 2.44 & ND & ND & ND & ND \\
\hline & Platelet & 0.55 & & 0.78 & & & & \\
\hline & Total & 2.78 & & 3.22 & & & & \\
\hline
\end{tabular}

Table 2. Total photosynthetically available radiation (PAR; $\mu \mathrm{E} \mathrm{m}^{-2} \mathrm{~s}^{-1}$ ) under quadrats with different snow cover

\begin{tabular}{|c|c|c|c|c|c|c|c|c|c|}
\hline \multirow[b]{2}{*}{ Snow $(\mathrm{cm})$} & \multicolumn{4}{|c|}{ Experiment I } & \multicolumn{5}{|c|}{ Experiment II (snow removed 3 Dec) } \\
\hline & $9 \mathrm{Nov}$ & 19 Nov & 30 Nov & $20 \mathrm{Dec}$ & $9 \mathrm{Nov}$ & $2 \mathrm{Dec}$ & $7 \mathrm{Dec}$ & $17 \mathrm{Dec}$ & $27 \mathrm{Dec}$ \\
\hline 0 & 90.5 & 4.7 & 136 & 74.0 & 6.4 & 207.3 & 107.1 & 133.0 & 73 \\
\hline 5 & 0.7 & 0.8 & 6.2 & 4.6 & $\cdots$ & 2.2 & 68.0 & 5.0 & 321 \\
\hline 10 & 0.4 & 4.1 & 1.1 & 42.0 & $\cdots$ & 1.5 & 102.0 & 94.9 & 231 \\
\hline 25 & 0.1 & 0.3 & 0.2 & 3.0 & $\cdots$ & 0.2 & 129.7 & 141.4 & 80 \\
\hline 100 & $\cdot$ & $\cdot$ & $\cdot$ & $\cdot$ & $\cdot$ & $\cdot$ & 141.5 & 104.1 & 231 \\
\hline \multicolumn{10}{|c|}{$\begin{array}{l}\therefore \text { Not detectable: }<0.02 \mu \mathrm{E} \mathrm{m}^{-2} \mathrm{~s}^{-1} \\
\therefore \text { Not determined }\end{array}$} \\
\hline
\end{tabular}

Table 3. Percent of surface downwelling irradiance (\% I) under quadrats with different snow cover

\begin{tabular}{|c|c|c|c|c|c|c|c|c|c|}
\hline \multirow[b]{2}{*}{ Snow $(\mathrm{cm})$} & \multicolumn{4}{|c|}{ Experiment I } & \multicolumn{5}{|c|}{ Experiment II (snow removed 3 Dec) } \\
\hline & 9 Nov & 19 Nov & $30 \mathrm{Nov}$ & $20 \mathrm{Dec}$ & 9 Nov & $2 \mathrm{Dec}$ & $7 \mathrm{Dec}$ & $17 \mathrm{Dec}$ & $27 \mathrm{Dec}$ \\
\hline 0 & 5.36 & 0.28 & 8.86 & 4.41 & 0.38 & 12.32 & 6.37 & 7.91 & 4.34 \\
\hline 5 & 0.04 & 0.05 & 0.37 & 0.28 & $\because$ & 0.13 & 4.05 & 0.30 & 19.10 \\
\hline 10 & 0.02 & 0.02 & 0.06 & 2.50 & $\cdots$ & 0.09 & 6.01 & 5.64 & 13.75 \\
\hline 25 & $<0.01$ & 0.02 & 0.01 & 0.18 & $\because$ & $<0.01$ & 7.68 & 8.39 & 4.76 \\
\hline 100 & $\cdot$ & $\cdot$ & $\cdot$ & $\cdot$ & $\cdots$ & $\cdot$ & 8.39 & 6.19 & 13.75 \\
\hline \multicolumn{10}{|c|}{$\begin{array}{l}\therefore \text { Not detectable: }<0.02 \mu \mathrm{E} \mathrm{m}^{-2} \mathrm{~s}^{-1} \\
\therefore \text { Not determined }\end{array}$} \\
\hline
\end{tabular}


spectra. The peak in spectral downwelling irradiance shifted to longer wavelengths (about $580 \mathrm{~nm}$ ); absorption in the 400 to $550 \mathrm{~nm}$ region, characteristic of absorption by diatom pigments, was particularly apparent on 19 November (Experiment I) and 9 November (Experiment II). Ablation of ice and loss of associated microalgae was indicated by a return to the $540 \mathrm{~nm}$ peak by late December. Similar patterns are seen

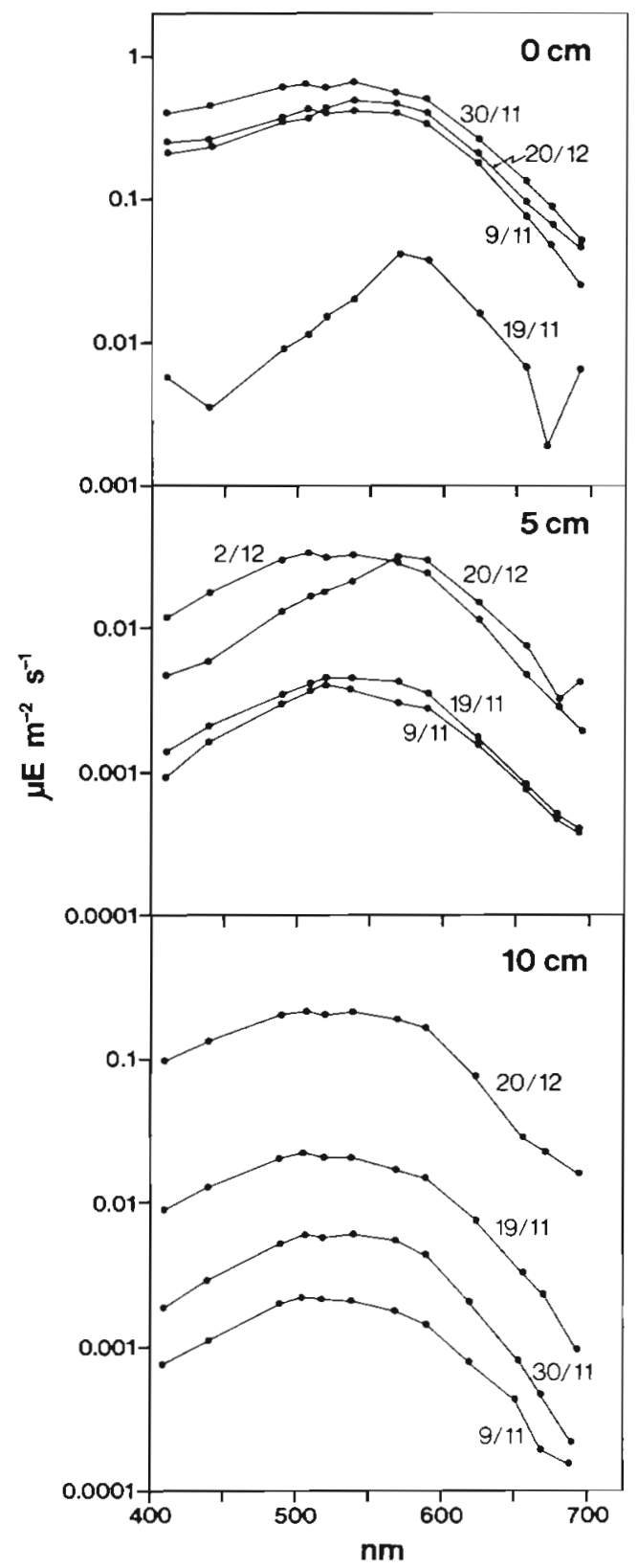

Fig. 1 Spectral irradiance beneath sea ice quadrats with 0,5 and $10 \mathrm{~cm}$ snow cover during the austral spring bloom of sea ice microalgae at Cape Armitage, McMurdo Sound. Underice spectral irradiance for $25 \mathrm{~cm}$ snow cover (not shown) was similar to $10 \mathrm{~cm}$ snow cover; irradiance beneath $100 \mathrm{~cm}$ snow cover was below detection

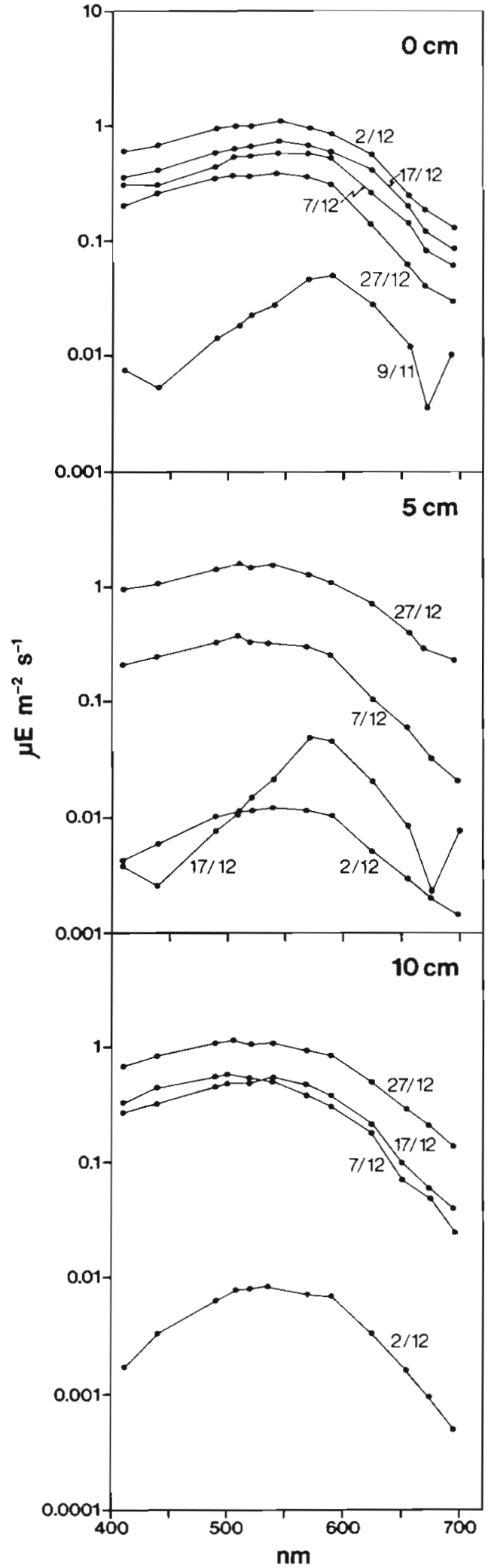

Fig. 2. Spectral irradiance beneath a set of quadrats parallel to those in Fig. 1, except that all snow was removed on 3 Dec 1982 
when under-ice spectral irradiance was plotted as a percent of surface downwelling irradiance (Fig. 3 \& 4).

The spectral diffuse attenuation coefficients, $K_{T}(\lambda)$ are shown in Fig. 5 (Experiment I) and Fig. 6 (Experiment II). Attenuation of light in the broad band

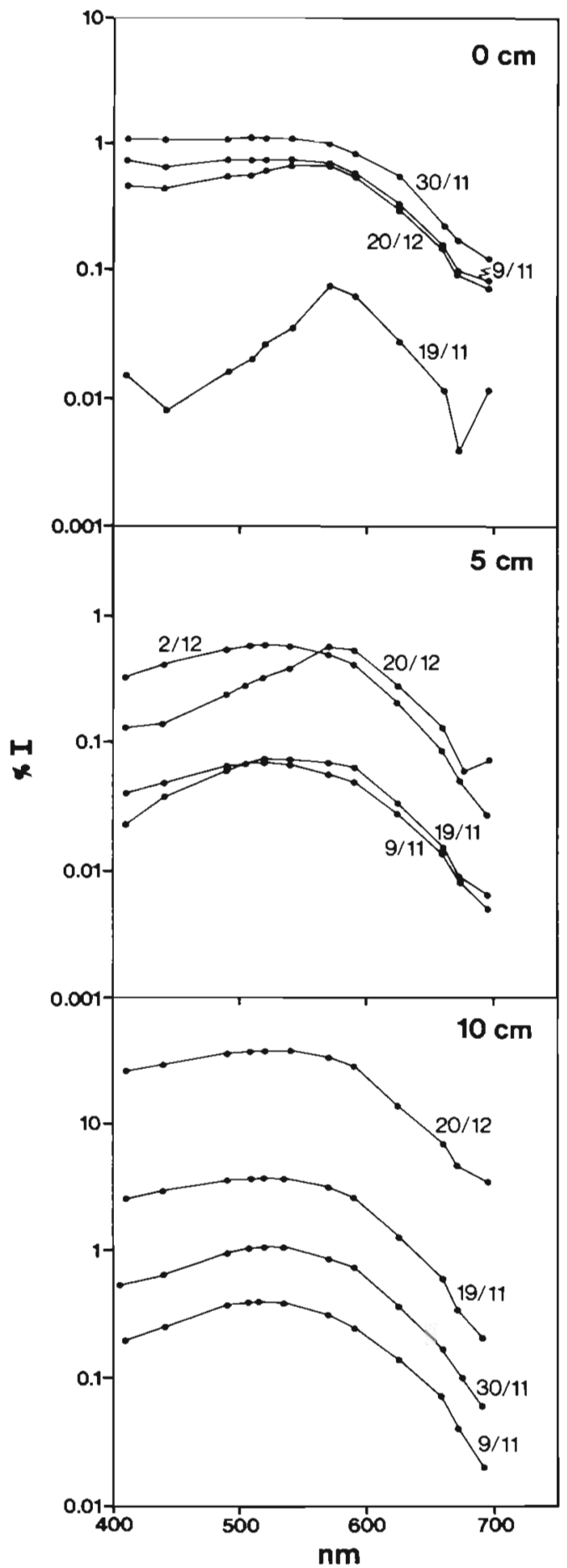

Fig. 3. Percent surface downwelling irradiance (\%l) for data in Fig. 1 between 400 and $550 \mathrm{~nm}$ and in the $671 \mathrm{~nm}$ band of the spectroradiometer indicates absorption by diatom pigments. In Experiment I, such a spectrum was evident on 19 November under $0 \mathrm{~cm}$ snow cover. Subsequently, spectra changed to show a pattern typical of

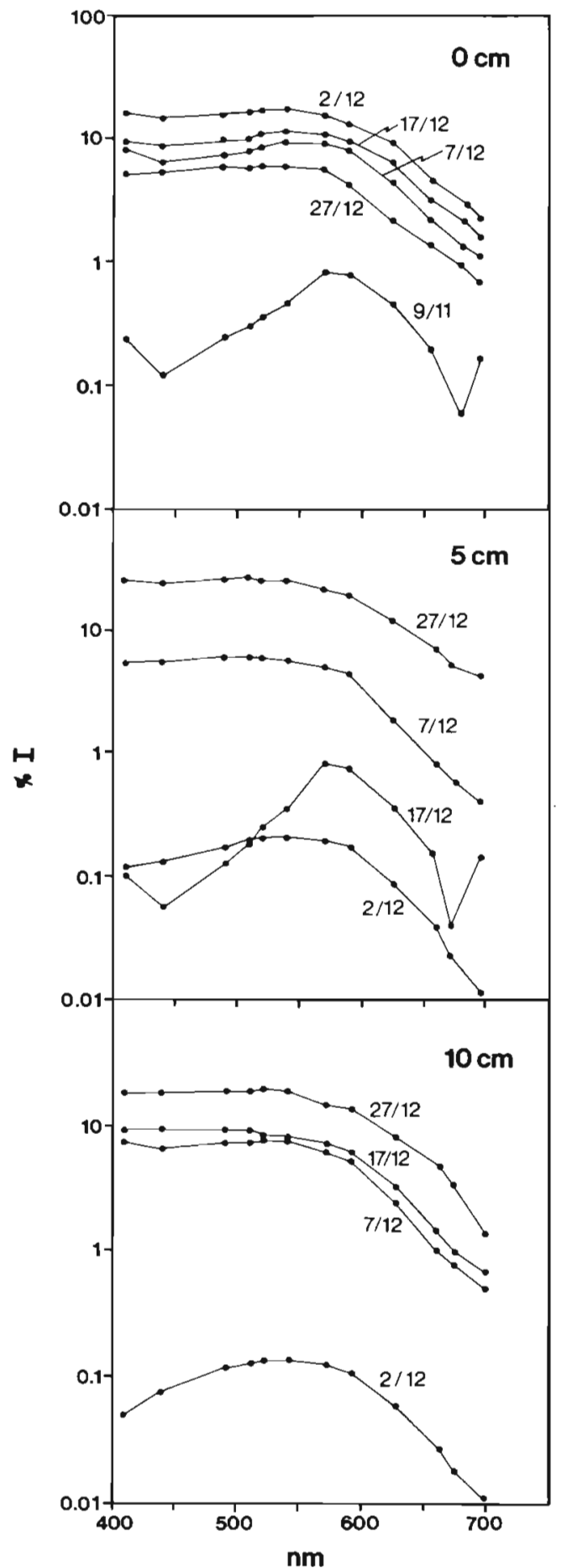

Fig. 4. Percent surface downwelling irradiance (\%I) for data in Fig. 2. Snow was removed on 3 Dec 1982 
under-ice spectra in the absence of a well-developed diatom community, i.e. enhanced absorption at longer wavelengths; this suggested the loss of the ice microalgal community. Under $5 \mathrm{~cm}$ snow cover, a slight increase in attenuation was observed in the 400 to $550 \mathrm{~nm}$ and $671 \mathrm{~nm}$ range but not until 20 December. There was no suggestion of absorption by diatom pigments under $10 \mathrm{~cm}$ snow cover. Attenuation of light by snow and ice under $10 \mathrm{~cm}$ snow cover decreased between 9 November and 20 December; this was prob-

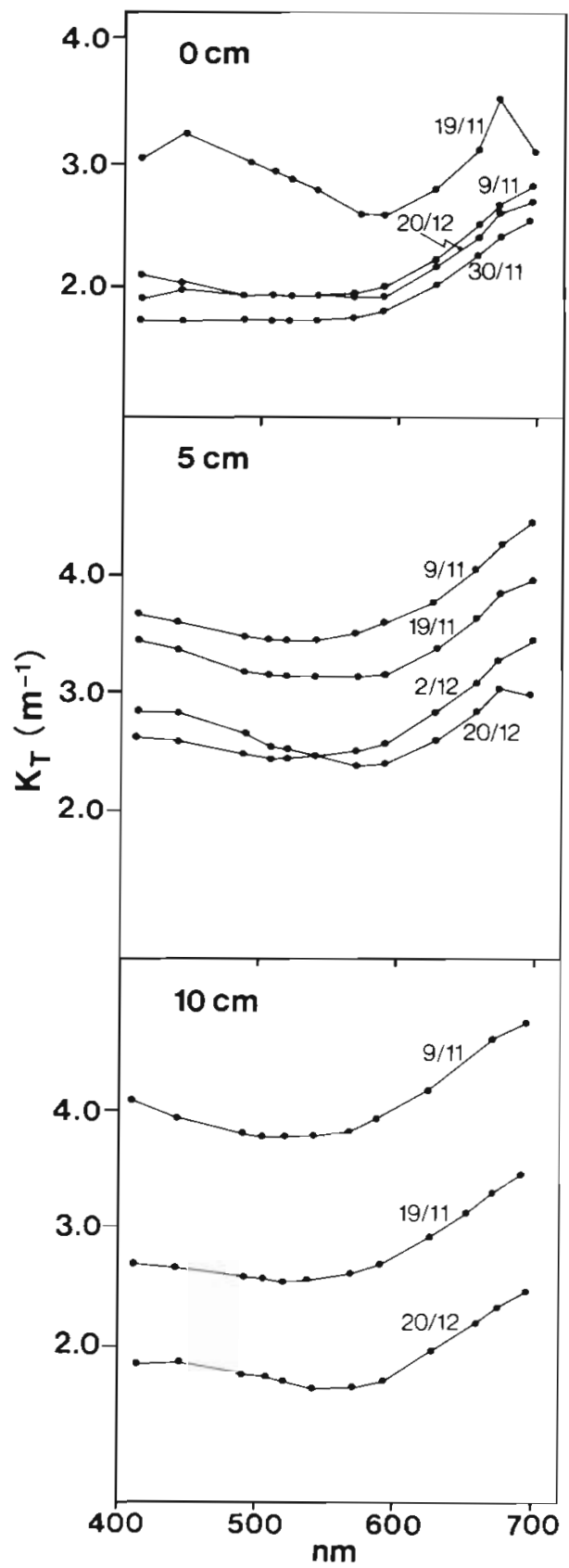

Fig. 5. Diffuse spectral attenuation coefficients, $K_{T}(\lambda)$, for data in Fig. 1 ably due to melting of surface snow and ice producing water-logged blue ice which resulted in lower light attenuation (Maykut \& Grenfell 1975).

In Experiment II (Fig. 6), a spectrum characteristic of algal absorption occurred only on 9 November under $0 \mathrm{~cm}$ snow cover. After snow was removed from the $5 \mathrm{~cm}$ quadrat, however, a spectrum typical of absorption by diatom pigments was obtained on 17 December. Despite clearing of snow from the $10 \mathrm{~cm}$ quadrat, there was no indication of light absorption by diatoms in this quadrat.

\section{DISCUSSION}

The rate and extent of development of sea ice microalgal communities were strongly affected by available

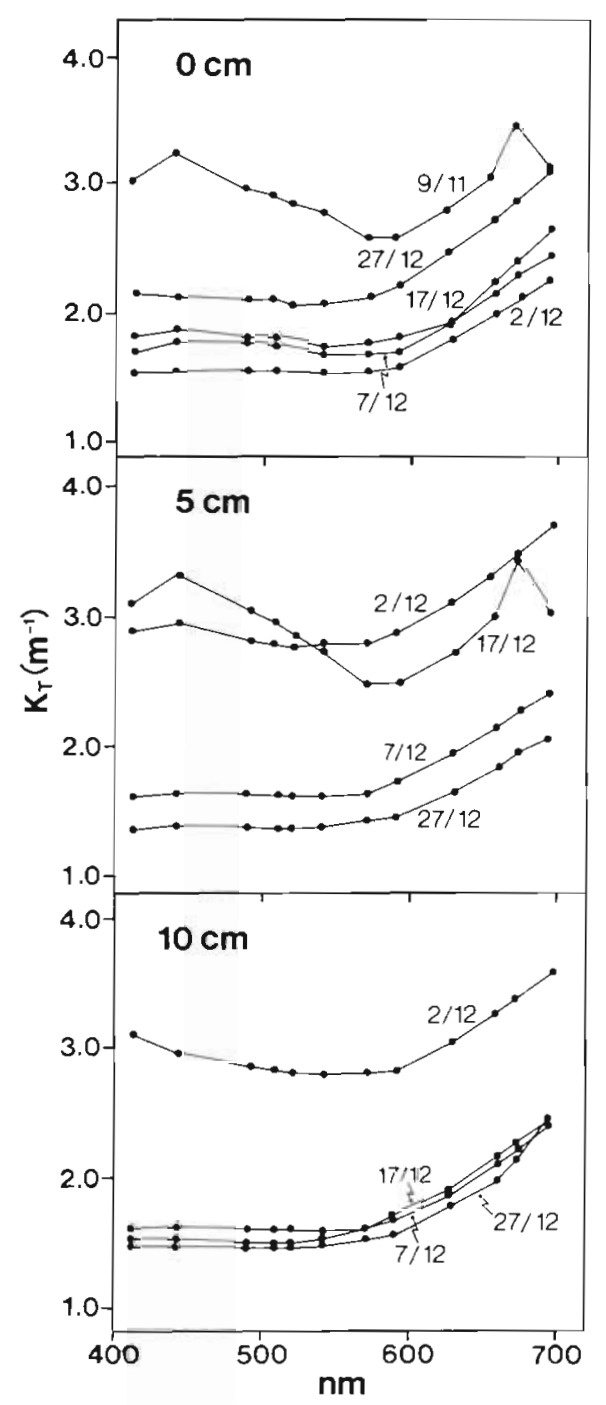

Fig. 6. Diffuse spectral attenuation coefficients, $K_{T}(\lambda)$, for data in Fig. 2. Snow was removed on 3 Dec 1982 
Table 4. Diffuse attenuation coefficients $K_{\mathrm{T}}(2).\left\{\mathrm{m}^{-1}\right\}$ under quadrats with different snow cover

\begin{tabular}{|c|c|c|c|c|c|c|c|c|c|}
\hline \multirow[b]{2}{*}{ Snow $(\mathrm{cm})$} & \multicolumn{4}{|c|}{ Experiment I } & \multicolumn{5}{|c|}{ Experiment II (snow removed 3 Dec) } \\
\hline & $9 \mathrm{Nov}$ & 19 Nov & $30 \mathrm{Nov}$ & $20 \mathrm{Dec}$ & 9 Nov & 2 Dec & $7 \mathrm{Dec}$ & $17 \mathrm{Dec}$ & $27 \mathrm{Dec}$ \\
\hline 0 & 2.10 & 2.92 & 1.84 & 2.12 & 2.93 & 1.70 & 1.76 & 2.00 & 2.40 \\
\hline 5 & 3.83 & 3.44 & 2.70 & 2.64 & $\cdot \cdot$ & 2.87 & 1.56 & 2.77 & 1.55 \\
\hline 10 & 4.26 & 3.00 & 3.06 & 2.03 & $\cdots$ & 2.96 & 1.61 & 1.71 & 1.74 \\
\hline 25 & 5.05 & 3.75 & 3.51 & 2.82 & $\cdots$ & 3.36 & 1.47 & 1.60 & 2.13 \\
\hline 100 & $\cdot$ & . & $\cdots$ & . & $\cdots$ & $\cdots$ & $\cdots$ & $\cdots$ & $\cdots$ \\
\hline$\therefore$ Not detectal & & & & & & & & & \\
\hline
\end{tabular}

irradiance. Removal of snow cover resulted in an increase in the rate of development and an early decline of sea ice microalgal communities (as described in companion report by Grossi et al.). The development of the ice algal community was suggested by the appearance of under-ice spectra characteristic of algal pigment absorption in mid-November (9 November in Experiment I; 19 November in Experiment II) followed by a spectral shift in late November suggesting the decline or disappearance of this community. By comparison, addition of as little as $5 \mathrm{~cm}$ of snow cover resulted in a delay in the algal bloom (until 20 December in Experiment I) and a reduction in the extent of that bloom, as indicated by under-ice spectra (Fig. 5) and by algal biomass estimates (Grossi et al. 1987). Further evidence of the importance of irradiance to community development came from Experiment II where removal of $5 \mathrm{~cm}$ of snow cover triggered an algal bloom within $2 \mathrm{wk}$, again indicated by a shift in under-ice spectra between 7 and 17 December (Fig. 6).

We have demonstrated that even a small increase in snow cover may have a considerable effect on the development of ice microalgal communities. Attenuation coefficients for natural snow cover are generally high (Warren 1982); values ranging from 16 to $45 \mathrm{~m}^{-1}$ have been reported (Thomas 1963, Weller \& Parker 1972, Grenfell \& Maykut 1977, Hameedi 1978). By subtracting light attenuation beneath bare ice from light attenuation beneath ice with $10 \mathrm{~cm}$ of snow cover (Experiment II; 2 and 7 December) we can estimate an attenuation coefficient for snow of $28 \mathrm{~m}^{-1}$. Although an approximation, this value falls within the range previously reported for dry, compact snow. The attenuation coefficient for ice is considerably less than that for snow; the $K_{T}$ for bare ice in the absence of microalgae (Experiment II $10 \mathrm{~cm}$ quadrat after snow removal) was $1.61 \mathrm{~m}^{-1}$. This value compares favorably with $\mathrm{K}_{\mathrm{T}}$ 's of 1.5 to $1.6 \mathrm{~m}^{-1}$ found by Grenfell \& Maykut (1977) for white ice in the Arctic Basin.

Sullivan et al. (1984) attempted to separate absorp- tion of light by sea ice from absorption by ice-associated microalgae. A difference spectrum was calculated in which $K_{T}(\lambda)$ in the absence of sea ice microalgae (Fig. 7 $A_{1}$ lower curve) was subtracted from $K_{T}(\lambda)$ in the presence of an ice algal bloom (Fig. 7A, upper curve). The resulting difference spectrum (Fig. 7B) was comparable to an in vivo absorbance spectrum of sea ice diatoms measured in the laboratory on a spectrophotometer. Both have a red absorbance peak characteristic of chlorophyll $a$ and a broad blue-green absorbance characteristic of chlorophyll $a$, chlorophyll $c$, and carotenoids.

Significant changes in under-ice spectra occurred on time scales as short as $10 \mathrm{~d}$. In Experiment I, estimated doubling times for algal communities based on chlorophyll a ranged from $1.7 \mathrm{~d}$ in the platelet below $0 \mathrm{~cm}$ snow cover to $23 \mathrm{~d}$ in the congelation ice beneath $100 \mathrm{~cm}$ snow cover (Grossi 1985). In general, changes in under-ice spectra were supported by biomass estimates; that is, the presence of spectra suggesting algal influence corresponded to peaks in chlorophyll a (Grossi et al. 1987). It is important to note, however, that the absence of an algal influence on under-ice spectra does not imply that algae were not present; rather, algae were not present in sufficient quantity to affect under-ice irradiance as detected with our spectroradiometer. For example, algal absorption was indicated in Experiment I under $5 \mathrm{~cm}$ on 20 December; at that time, standing stock of chlorophyll $a$ in both congelation and platelet ice totaled about $44 \mathrm{mg} \mathrm{chl} \mathrm{a} \mathrm{m}^{-2}$ (Grossi et al. 1987). In contrast, under $25 \mathrm{~cm}$ of snow on that date, presence of about $6 \mathrm{mg} \mathrm{chl} \mathrm{a} \mathrm{m}^{-2}$ failed to appreciably influence the under-ice spectra.

The development of sea ice microalgal communities affected under-ice spectral irradiance available to phytoplankton and benthic algae beneath annual sea ice. Ice algae act as a filter, absorbing wavelengths critical to photosynthesis decreasing not only PAR, but also PUR (photosynthetically usable radiation; Morel 1978). PUR was defined by Morel as the fraction of radiant energy of such a wavelength that it can be absorbed by 

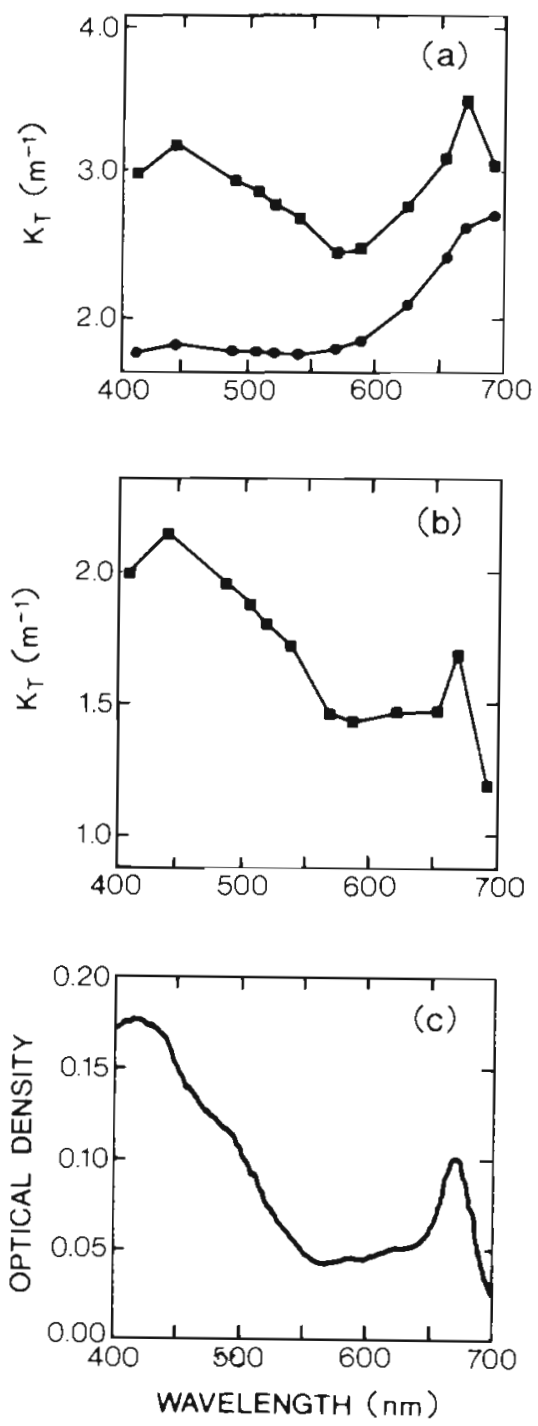

Fig. 7. (a) Diffuse spectral attenuation coefficients, $K_{\mathrm{T}}(\lambda)$, below sea ice on 7 Dec 1982, prior to the development of a sea ice microalgal community (Iower curve), and on 17 Dec after a community had developed (upper curve). (b) Difference spectrum for the 2 curves in (a). (c) Absorption spectrum of sea ice microalgal sample measured in the laboratory (from Sullivan et al. 1984]

the algae'. It has been suggested that water column and benthic productivity are primarily limited to before or after the ice algal bloom (Bunt 1964, Palmisano et al. 1985).

Absorption of irradiance by the sea ice microalgae also affects the rate of ice ablation (Buynitsky 1968). It is hypothesized that the dark layer absorbs infrared wavelengths resulting in localized warming leading to melting, although no direct measurements have been reported. The most densely colonized $0 \mathrm{~cm}$ quadrat,

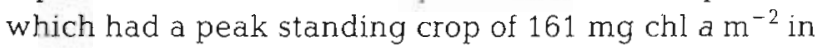
Experiment $I$, was also the earliest to ablate.
We propose that changes in sea ice microalgal biomass result from both physical and biological processes. Increases in algal biomass result from growth and cell division of algae and from physical processes of ice accretion (Sullivan et al. 1985); for example, Garrison et al. (1983) showed that algae may be concentrated during frazil ice formation. Algae may also possibly serve as ice-nucleating sites, or may become attached to ice surfaces during ice formation. On the other hand, losses in algal biomass may result from a grazing by microzooplankton at the ice-seawater interface, or by cell death. Ice ablation or melting is also a major factor in the loss of the ice algal community. These processes are summarized in the following equation:

$$
\frac{\Delta \text { Algal biomass }(\mathrm{chl} \text { a) }}{\Delta \mathrm{t}}=\begin{gathered}
\text { (Growth }+ \text { Accretion })-(\text { Grazing } \\
+ \text { Ablation }+ \text { Death })
\end{gathered}
$$

Although greatly simplified, this preliminary model includes major factors determining algal standing stocks in the fast-ice community at Cape Armitage, McMurdo Sound.

AcknowJedgements. The authors thank Dr. T. Grenfell and an anonymous reviewer for comments on the manuscript; Drs. Grenfell and S. Warren for assistance with albedo measurements; Dr. S. Grossi and Dr. S. Kottmeier for providing chlorophyll a data and for field assistance; Mr. J. Wood and Dr. G. T. Taylor for dive support. This research was supported by National Science Foundation grant DPP 81-17237 to CWS.

\section{LITERATURE CITED}

Baker, K. S., Smith, R. C. (1982). Bio-optical classification and model of natural waters. Limnol. Oceanogr. 27: 500-509

Bunt, J. S. (1963). Diatoms of antarctic sea ice as agents of primary production. Nature, Lond. 199: 1255-1257

Bunt, J. S. (1964). Primary productivity of undersea ice in Antarctic waters. Influence of light and other factors on photosynthetic activities of Antarctic marine microalgae. Antarct. Res. Ser. 1: 27-31

Bunt, J. S., Lee, C. C. (1970). Seasonal primary production in Antarctic sea ice at McMurdo Sound in 1967. J. mar. Res. 28: $304-320$

Buynitsky, V. K. (1968). The influence of microalgae on the structure and strength of Antarctic sea ice. Oceanology 8: $771-776$

Garrison, D. L., Ackley, S. F., Buck, K. R. (1983). A physical mechanism for establishing algal populations in frazil ice. Nature, Lond. 306: 363-365

Grenfell, T C., Maykut, G. A. (1977). The optical properties of ice and snow in the Arctic Basin. J. Glaciol. 18: 445-463

Grossi, S. M. (1985). Response of a sea ice microalgal community to a gradient in under-ice irradiance. Ph.D. dissertation. Unuv. of Southern California, Los Angeles

Grossi, S. M., Kottmeser, S. T., Moe, R. L., Taylor, G. T., Sullivan, C. W. (1987). Sea 1ce microbial communities. VI. Growth and primary production in bottom ice under graded snow cover. Mar. Ecol. Prog. Ser. 35: 1.53-164 
Hameedi, M. J. (1978). Aspects of water column primary productivity in the Chukchi Sea during summer. Mar. Biol. 98: $37-46$

Jerlov, N. G. (1976). Marine optics. Elsevier Oceanography Series, Vol. 14. Elsevier, Amsterdam, p. 115

Kiefer, D. A., SooHoo, J. B. (1982). Spectral absorption by marine particles of coastal waters of Baja California. Limnol. Oceanogr. 27: 492-499

Kirk, J. T. O. (1975). A theoretical analysis of the contribution of algal cells to the attenuation of light within natural waters. 1. General treatment of suspensions of pigmented cells. New Phytol. 75: 11-20

Kishino, M., Booth, C. R., Okami, N. (1984). Underwater radiant energy absorbed by phytoplankton, detritus, dissolved organic matter, and pure water. Limnol. Oceanogr. 29: $340-349$

Mann, J. E., Myers, J. (1968). Photosynthetic enhancement in the diatom Phaeodactylum tricornutum. Pl. Physiol., Wash. 43: 1991-1995

Maykut, G. A., Grenfell, T. C. (1975). The spectral distribution of light beneath first-year sea ice in the Arctic Ocean. Limnol. Oceanogr. 20: 554-563

Morel, A. (1978). Available, usable, and stored radiant energy in relation to marine photosynthesis. Deep Sea Res. 25: $673-688$

Palmisano, A. C., Sullivan, C. W. (1983). Sea ice microbial communities 1. Distribution, abundance, and primary production of ice microalgae in McMurdo Sound, Antarctica in 1980. Polar Biol. 2: 171-177
Palmisano, A. C., SooHoo, J. B., White, D. C., Smith, G. A., Stanton, G. A., Burckle, L. (1985). Shade adapted benthic diatoms beneath annual antarctic sea ice. J. Phycol. 21: $664-667$

Sullivan, C. W., Palmisano, A. C., Kottmeier, S. T., Grossi, S. M., Moe, R. L., Taylor, C. T. (1983). The influence of light on development and growth of sea-ice microbial communities in McMurdo Sound. Antarct. J. U.S. 18: 177-179

Sullivan, C. W., Palmisano, A. C., Kottmeier, S. T., Moe, R. L. (1982). Development of the sea ice microbial community in McMurdo Sound. Antarct. J. U.S. 17: 155-157

Sullivan, C. W., Palmisano, A. C., SooHoo, J. B. (1984). Influence of sea ice and sea ice biota on downwelling irradiance and spectral composition of light in McMurdo Sound. SPIE Vo. 489 Ocean Optics VII: 159-165

Sullivan, C. W., Palmisano, A. C., Kottmeier, S., Grossi, S. M. Moe, R. (1985). The influence of light on growth and development of the sea ice microbial community in McMurdo Sound. In: Siegfried, R., Condy, P. R., Laws, R. M. (ed.) Fourth SCAR Symposium on Antarctic Biology, Nutrient Cycles and Food Webs. Springer-Verlag, Berlin, p. $78-83$

Thomas, C. W. (1963). On the transfer of visible radiation through sea ice and snow. J. Glaciol. 4: 481-484

Warren, S. G. (1982). Optical properties of snow. Rev. Geophys. Space Phys. 20:67-89

Weller, G., Parker, S. (1972). Radiation regime of the Arctic Basin - studies at T-3 AIDJEX sites and Barrow. Tech. Rep. Geophys. Inst., Univ. Alaska, Vol, 2, p. 4-11

This article was submitted to the editor; it was accepted for printing on November 4, 1986 